\title{
Prospects of fibrinolytic proteases of bacteria from sea cucumber fermentation products as antithrombotic agent
}

\author{
Hayatun Fuad ${ }^{1}$, Nur Hidayati $^{1}$, Sri Darmawati ${ }^{1,2}$, Hendra Munandar ${ }^{3}$, Ayu Rahmawati Sulistyaningtyas $^{2}$, Nurrahman \\ Nurrahman $^{2}$, Aditya Rahman Ernanto ${ }^{2}$, Dewi Seswita Zilda ${ }^{4}$, Widjanarka Widjanarka 5 , and Stalis Norma Ethica ${ }^{1,2^{*}}$ \\ ${ }^{1}$ Medical laboratory Science Study Program, Universitas Muhammadiyah Semarang, J1. Kedungmundu No.18, Semarang, Jawa \\ Tengah, 50273 Indonesia \\ ${ }^{2}$ Faculty of Nursing and Health Sciences, Universitas Muhammadiyah Semarang, Jl. Kedungmundu No.18, Semarang, Jawa Tengah, \\ 50273 Indonesia \\ ${ }^{3}$ Balai Bio Industri Laut-LIPI (Laboratorium Ilmu Pengetahuan Indonesia), Lombok, Nusa Tenggara Barat, Indonesia \\ ${ }^{4}$ Research and Development Center for Marine and Fishery Product Processing and Biotechnology, Ministry of Maritime Affairs and \\ Fisheries of Indonesia, Indonesia \\ ${ }^{5}$ Biology Laboratory, Faculty of Mathematics and Natural Sciences, Universitas Diponegoro, Jl. Prof. Sudarto No.13, Tembalang, \\ Semarang, Jawa Tengah 50275, Indonesia
}

\begin{abstract}
Cardiovascular disease is among the largest contributors of premature mortality in the world caused by inflammation of blood vessels. The abnormalities provoke thrombus formation or thrombosis blocking blood vessels leading to strokes, heart attacks and coronary artery diseases. Increasing percentage of cardiovascular cases and deaths due to thrombosis has attracted researchers to look for newer thrombolysis agents. Commonly used drugs to treat thrombosis has been limited due to various side effects. Therefore, the search for sources of safer and cheaper fibrinolytic enzymes for handling thrombolysis continues. This study aimed to evaluate potentials of fibrinolytic protease of bacteria isolated from fermented seafood (sea cucumber) products as antithrombotic agents. Information was initially gathered from scientific publications identified using web-based tools including PubMed (National Center for Biotechnology Information), Science Direct (Scopus) and Web of Science (Thomson Reuters) using combinations of search terms including "fibrinolytic enzyme protease", "endopeptidase", "fermented food", "sea cucumber", "thrombolysis therapy," "thrombolytic agent," "fibrinolytic bacteria," "fibrinolysis," "protease producing bacteria," "fibrin degradation," "holothurians," etc. We also searched for these terms in national and international organization technical reports and databases. This literature review reveals the prospects of fibrinolytic protease enzymes from bacteria from fermented seafood, particularly sea cucumber as novel antithrombotic agents.
\end{abstract}

Keywords: Cardiovascular disease, fermented seafood, fibrinolytic protease, thrombotic agent

\section{Introduction}

Cardiovascular disease (CVD) is leading cause of disability and premature all over the world due to the formation of thrombus in the walls of blood vessels causing heart disease such as stroke, heart attack and coronary artery disease. Increasing percentage of cardiovascular cases and deaths due to thrombosis worldwide has attracted researchers to look for agents that are more recent in degrading thrombus [1-5].

Common drugs that have been used to treat thrombosis include urokinase, tissue type plasminogen activator (t-PA) and streptokinase. The drugs work by activating plasminogen and then transforming plasminogen into plasmin. This action will degrade fibrin. However, the use of these agents has been limited due to various side effects including high price, half-life issues, allergy risks and administration problem. It has urged researchers to keep seeking for fibrinolytic enzymes with better characteristics for thrombolysis treatment [2].

In the last decades, many thrombolytic agents have been identified, studied and characterized from various sources such as earthworms, snakes, fungi, and bacteria. Bacteria have the potential to produce economically valuable enzymes with several advantages, including faster growth, scale of cell production will be more easily increased, production conditions do not depend on the season, short-time required, low cost, high activity, safe and not toxic and easily manipulated genetically $[4,6,7]$. Therefore, research about anti thrombolytic agents from new fibrinolytic protease producing bacteria must be done because more effective and efficient anti thrombolytic agents are still needed.

Fibrinolytic proteases in fermented seafood products other than shrimp and fish, i.e. sea cucumber, has not been reported. Sea cucumbers, which belong to the class Holothuroidea, have been known to possess high commercial value and have long been used for food and

\footnotetext{
* Corresponding author: snorma@unimus.ac.id
} 
medicine with impressive profile of valuable nutrients including proteins and minerals [8]. Therefore, it is important to conduct research on the fibrinolytic activity of bacterial strains which is isolated from sea cucumber fermentation products is interesting to do [9]. This work aimed to evaluate prospect of bacterial fibrinolytic protease enzyme from fermentation products of seafood (especially sea cucumber) as an antithrombotic agent based on literature review.

\section{Methods}

This systematic review was carried out to determine prospect of developing anti thrombolytic agents from fibrinolytic protease of bacteria isolated from fermented sea cucumber. It is expected that the obtained anti thrombolytic agents can be used as an alternative medicine with better economic value, high activity and safer to deal with cardiovascular disease in Indonesia and the world. Eligibility criteria, identification of relevant studies, study selection, and control research bias were determined following previous procedures [10].

\subsection{Eligibility criteria for study}

First, types of thrombolytic agents that have been used in thrombosis treatment throughout the world were summarized, including the types of bacteria producing them. Study selection was based on the following inclusion criteria: [i] studies with limited subjects for treatment applied to cardiovascular disease; [ii] published in English; [iii] studies that evaluate the knowledge and practice of treatment of cardiovascular disease throughout the world as a result of measuring to find out how widespread the use of bacteria as antithrombolytic agents; [iv] observational study. The publication date was limited to the last 10 years considered in the search strategy.

A summary of the use of fibrinolytic protease bacteria as anti-thrombolytic agents in Indonesia was carried out to indicate the potential of using fibrinolytic protease bacteria as thrombolytic agent. The selection of studies was carried out based on the following inclusion criteria: [i] evaluation studies using knowledge and practice of using fibrinolytic protease bacteria in the treatment of cardiovascular disease as an outcome measure in Indonesia. [ii] subjects related to treatment using fibrinolytic protease bacteria in Indonesia are applied for cardiovascular disease; [iii] published in both languages namely Indonesian and English; [iv] observational studies. As part of the search strategy, the year of publication is also limited to the last 10 years.

\subsubsection{Identification of relevant studies}

This literature review was carried out in both manual and non-manual ways based on previous protocol [1011]. A search for relevant studies was conducted in 2 categories: 1. Enzyme fibrinolytic proteases from fermented foods. 2. Purification and characterization of fibrinolytic protease enzymes. For the first category, electronic literature and initial manual searching through PubMed and Science Direct Database as well as manual searches regardless of publication date were carried out using the term MESH-- fibrinolytic enzyme protease; enzymes; endopeptidases; seafood; fermentation; thrombolysis therapy; sea cucumber; holothurian. Full text of all articles was extracted by electronics and manual searches from PubMed and Science Direct. The studies released from this review were: [i] studies conducted after 2010 [ii] studies of fibrinolytic protease enzymes isolated from groups of bacteria in fermented products in Indonesia; [iii] reviews; [iv] study of important fibrinolytic enzymes in thrombolysis [v] study of fibrinolytic enzymeproducing bacteria [vi] study of fibrinolytic enzymeproducing bacteria in food products. For the second category, computerized literature searches through PubMed (National Center for Biotechnology Information 2019), Science Direct (Scopus 2019) and Web of Science (Thomson Reuters 2019), as well as manual searches regardless of date of publication are carried out using the MESH query for the treatment of thrombolytic or fibrinolytic protease enzymes from food fermented products. A variety of keywords are used in search strategies including thrombolysis therapy, fibrinolytic protease enzymes, fibrinolytic proteaseproducing bacteria, fibrin degradation. Various keyword combinations are created using 'and', 'or' as Boolean operators. The relevant subject matter experts and selected study authors were also contacted to obtain missing or unclear data whenever it was considered important. The studies excluded from this review were: [i] studies conducted before 2010 [ii] patents.

\subsubsection{Study selection}

Three authors (HF, SNE, and HM) independently identified literature that fulfil the inclusion criteria in this review. Full text articles from the remaining studies taken fulfil the inclusion criteria. Observational studies were filtered using the STROBE checklist

\subsubsection{Control research bias}

The following issues were included in the risk of bias or quality of assessment in this systematic review: (i) completeness of reporting information on the fibrinolytic protease enzymes produced by bacteria in food fermentation products, (ii) selective yield reporting, (iii) selection of outcome measures [practice test the ability of thrombosis agents using fibrinolytic protease bacteria applied during cardiovascular treatment in Indonesia], (iv) research design, and (v) inter-conflict conflict in conducting research. When the overall criteria were met, the risk of a reasonable bias overall was regarded low.

\subsubsection{Data collection and extraction}

This review had been carried out based on the established guidelines submitted by Choice Reporting Items for Systematic Review and META Analysis 
[PRISMA] [12]. Four writers (ARS, SD, DSZ, \& NH) were responsible for extracting data from research. From each study, the predetermined data extracted included the research design, sample size, treatment of cardiovascular disease among study subjects around the world, and knowledge related to the use of microbial fibrinolytic protease-producing enzymes to deal with various cardiovascular diseases.

\section{Literature review}

\subsection{Importance of fibrinolytic enzymes in thrombolysis}

Table 1 summarises cases of Cardiovascular disease (CVD) and reported mechanism of treatment by drugs in the last decade. From the data, it can be seen that thrombolysis/ fibrinolysis treatment is still widely used to date. The known mechanism of the treatment basically utilizing drugs targeting the degradation of fibrin by plasmin activation.

Table. 1 Current CVD cases and related treatment reported in the last decade

\begin{tabular}{|c|c|c|c|}
\hline Case & Mechanism of Treatment & Region & Source, Year \\
\hline $\begin{array}{l}\text { Stroke, thrombosis, embolism, } \\
\text { atherosclerosis }\end{array}$ & Hydrolysing fibrin & Indonesia & {$[1]$} \\
\hline Heart \& cerebrovascular disease & Hydrolysing fibrin & Vietnam & [13] \\
\hline Heart attack \& stroke & Dissolving fibrin lumps & China & {$[14]$} \\
\hline Coronary heart disease $\&$ atherosclerosis & Blocking thrombus & China & {$[15]$} \\
\hline $\begin{array}{l}\text { Myocardial infarction \&coronary heart } \\
\text { disease }\end{array}$ & Hydrolysing fibrin & China & {$[16]$} \\
\hline Myocardial infarction \& thrombosis & Hydrolysing fibrin & Indonesia & {$[17]$} \\
\hline Stroke \& coronary artery disease & Dissolving fibrin clots & Vietnam & {$[4]$} \\
\hline Thrombosis & Hydrolysing fibrin & Taiwan & {$[18]$} \\
\hline Myocardial infarction & Hydrolysing fibrin & Korea & [19] \\
\hline Heart attack \& coronary thrombosis & Breaking down fibrin & India & {$[20]$} \\
\hline Myocardial infarction & Degrading fibrin & China & {$[21]$} \\
\hline $\begin{array}{l}\text { Myocardial infarction, thrombosis \& } \\
\text { embolism }\end{array}$ & Preventing thrombus formation & Korea & {$[22]$} \\
\hline Heart disease \& stroke & Hydrolysing fibrin & Indonesia & {$[2]$} \\
\hline $\begin{array}{l}\text { Thrombus \& vascular cardiovascular } \\
\text { disease. }\end{array}$ & Hydrolysing fibrin & China & {$[23]$} \\
\hline $\begin{array}{l}\text { Myocardial infarction \& ischemic heart } \\
\text { disease }\end{array}$ & Hydrolysing the $\alpha, \beta \& \gamma$ chains & Korea & {$[24]$} \\
\hline Myocardial dial infarction \& stroke & Converting plasminogen & India & {$[25]$} \\
\hline $\begin{array}{l}\text { Pulmonary embolism, myocardial } \\
\text { infarction }\end{array}$ & Degrading fibrin & China & {$[26]$} \\
\hline $\begin{array}{l}\text { Acute myocardial infarction \& brain } \\
\text { infarction }\end{array}$ & Dissolving fibrin inside blood & Korea & {$[27]$} \\
\hline $\begin{array}{l}\text { Myocardial infarction \& cardiovascular } \\
\text { infarction }\end{array}$ & Degrading $\alpha \& \beta$ chains & Korea & {$[28]$} \\
\hline
\end{tabular}




\subsection{Study of bacterial diversity isolated from seafood fermented products}

Studies of bacterial diversity isolated from fermented food products have been conducted in many countries, although the frequency is not as often as that isolated from other ingredients. Diversity of bacteria in fermented foods is found, most of bacteria has identified as bacteria Bacillus sp. It could be seen from Table 2 and 3 that group of bacteria that produce fibrinolytic protease enzymes applied to cardiovascular disease mostly use Bacillus sp. species bacteria. Based on 19 literatures reviewed, all of the bacteria producing fibrinolytic protease enzymes reported from all over the world in the last decade were mostly used in the treatment of cardiovascular disease (Table 2).

\subsection{Fibrinolytic protease enzymes from bacteria isolated from fermentation products}

Studies about diversity of fibrinolytic protease enzymes from bacteria isolated from fermented foods have been carried out in many countries although their frequency is not as often as that isolated from other ingredients. For example, Stephani (2017) reported about bacterial populations that produce fibrinolytic protease enzymes in red oncom products is carried out in Indonesia [1]. The results showed that the bacteria isolated from red oncom with fibrin degradation potential consisted of Bacillus licheniformis, B.cereus, B.licheniformis, dan B. cereus. Meanwhile, molecular analysis of a potential bacterial thrombolytic agent from Douchi-China was successfully carried out by Hu (2019) [16]. The study conducted genetic diversity analysis based on the bacterial 16S rRNA gene.

Table. 2 Biodiversity study on protease producing bacteria from various fermented products in the last decade

\begin{tabular}{|c|c|c|}
\hline Fermented Food Product & Isolated Bacteria & Source, Year \\
\hline Soy Meju & B. amyloliquefaciens MJ5-41 & Jo et al., 2011 [28] \\
\hline Fermented Chickpeas & B. amyloliquefaciens & Wei et al., 2011 [23] \\
\hline Soy Meju & B. amyloliquefaciens MJ5-41 & Jo et al., 2011 [28] \\
\hline Red bean Natto & B. subtilis & Chang et al., 2012 [18] \\
\hline Soy Douchi & B. subtilis LD-8547 & Yuan et al., 2012 [15] \\
\hline Soy \& cheese Doufuru & B. subtilis & Chen et al., 2013 [14] \\
\hline Salted fish \& shrimp Terasi & B. coagulans & Prihanto et al., 2013 [29] \\
\hline Soy Douchi & B. amyloliquefaciens DC-4 & Zhang et al., 2013 [26] \\
\hline Soy Cheonggukjang & B. amyloliquefaciens $\mathrm{CB} 1$ & Heo et al., 2013 [27] \\
\hline Soy Gembus & B. pumilus 2.g & Afifah et al., 2014 [2] \\
\hline Fermented Indian rice & B. cereus IND1 & $\begin{array}{l}\text { Vijayaraghavan \& Vincent, } 2014 \\
{[25]}\end{array}$ \\
\hline Shrimp Terasi & Lactobacillus plantarum & Sulthoniyah et al., 2015 \\
\hline Fermented shrimp paste & B. weihenstephanensis, Bacillus sp. & Anh et al., 2015 [4] \\
\hline Soy Cheonggukjang & B. subtilis HK176 & Jeong et al, 2015 [24] \\
\hline Green chili, soy Miso & B. amyloliquefaciens FZB42 & Huy et al., 2016 [13] \\
\hline Soy Oncom & Bacillus spp.. & Nailufar et al., 2016 [17] \\
\hline Soy Doenjang & Bacillus spp. & Jeon et al., 2016 [30] \\
\hline Soy Doenjang & B. amyloliquefaciens RSB34 & Yao et al., 2017 [31] \\
\hline Fermented rice & B. sp. IND6 & Almalki et al., 2017 [32] \\
\hline $\begin{array}{l}\text { Red oncom, fermented soybean/ tofu } \\
\text { dregs }\end{array}$ & Bacillus spp. \& Stenotrophomonas sp. & Stephani et al., 2017 [1] \\
\hline Flour Dosa Batter & B. amyloliquefaciens MCC 2606 & Devaraj, 2018 [20] \\
\hline Small shrimp Jeotgal & B. subtilis JS2 & Yao et al., 2018 [9] \\
\hline Soy fermented Oncom & B. megaterium & Lestari et al., 2018 [33] \\
\hline Soy Gembus & Pseudomonas stutzeri ISTD4 & Inayatul et al., 2018 [34] \\
\hline Soy red Oncom & B. thuringiensis IRODI & Safitri et al., 2018 [35] \\
\hline Soy red Oncom & S. hominis & Harun et al., 2018 [36] \\
\hline Soy Douchi & B. subtilis DC27 & Hu et al., 2019 [16] \\
\hline White shrimp Rusip & S. cohnii IRLV5 & Japri et al., 2019 [37] \\
\hline White shrimp Rusip & S. epidermidis & Fazri et al., 2019 [38] \\
\hline
\end{tabular}


The diversity of bacteria in fermented foods brings the flexibility to find groups of fibrinolytic bacteria that produce various enzymes that are able to degrade fibrin. By conducting biodiversity study, it is expected that the bacterial group could be selected, tested and then used as a new antithrombotic agent.

\subsection{Fibrinolytic enzymes producing bacteria}

Table 3 summarised biodiversity studies conducted to isolate proteolytic bacteria from various fermented foods in various countries. It was found that majority of proteolytic bacteria isolated from fermented foods belong to Bacillus group. It is also confirmed by data in Table 2 and 3 that there are no other fermented sea food products other than fish (catfish) and shrimp used as samples to isolate fibrinolytic enzyme producing bacteria.

Based on the summarised data, study aiming at production of fibrinolytic enzymes from bacteria isolated from fermented sea cucumber as a rich protein source is potential to be done. It offers novelty, yet potential considering that reports about sea cucumber fermentation could not been found during this review process. A scheme showing potential of fibrinolytic protease enzymes of bacteria from sea cucumber fermentation products as antithrombotic agent is presented in Figure 1.

Table. 3 Fibrinolytic enzyme producing bacteria from food

\begin{tabular}{lllll}
\hline Species & Application & Food Sample & Country & Source, Year \\
\hline B. amyloliquefaciens & Thrombolytic agent & Chickpeas & China & {$[23]$} \\
B. amyloliquefaciens MJ5-41 & Thrombolytic agent & Meju & Korea & {$[28]$} \\
B. subtilis & Thrombolytic agent & Natto-red bean & Taiwan & {$[18]$} \\
B. subtilis LD-8547 & Thrombolytic agent & Douchi & China & {$[15]$} \\
Bacillus subtilis & Thrombolytic agent & Doufuru & China & {$[14]$} \\
B. coagulans & Fibrinolytic agent & Fermented Fish & Indonesia & {$[29]$} \\
B. amyloliquefaciens DC-4 & Fibrinolysis agent & Douchi & China & {$[26]$} \\
B. amyloliquefaciens CB1 & Fibrinolysis agent & Cheonggukjang & Korea & {$[27]$} \\
B. pumilus 2.g & Thrombolytic agent & Gembus & Indonesia & {$[2]$} \\
Bacillus sp. & Thrombolytic agent & Fermented shrimp paste & Vietnam & {$[4]$} \\
B. cereus IND1 & Thrombolytic agent & Indian rice & India & {$[25]$} \\
B. subtilis HK176 & Thrombolytic agent & Cheonggukjang & Korea & {$[24]$} \\
Bacillus sp. & Hemolytic agent & Doenjang & Korea & {$[30]$} \\
B. amyloliquefaciens FZB42 & Thrombolytic agent & Green chili miso & Vietnam & {$[13]$} \\
Bacillus sp. \& Stenotrophomonas sp. & Thrombolytic agent & Oncom & Indonesia & {$[17]$} \\
Stenotrophomonas sp. & Thrombolytic agent & Oncom & Indonesia & {$[1]$} \\
Bacillus sp. IND6 & Thrombolytic Agent & Fermented rice & Saudi Arabia & {$[32]$} \\
B. amyloliquefaciens RSB34 & Thrombolytic agent & Doenjang & Korea & {$[31]$} \\
B. subtilis JS2 & Fibrinolysis agent & Saeu jeotgal & Korea & {$[31]$} \\
B. amyloliquefaciens MCC2606 & Thrombolytic agent & Soy & India & {$[20]$} \\
B. subtilis DC27 & Thrombolytic agent & Douchi & China & {$[16]$} \\
\hline
\end{tabular}

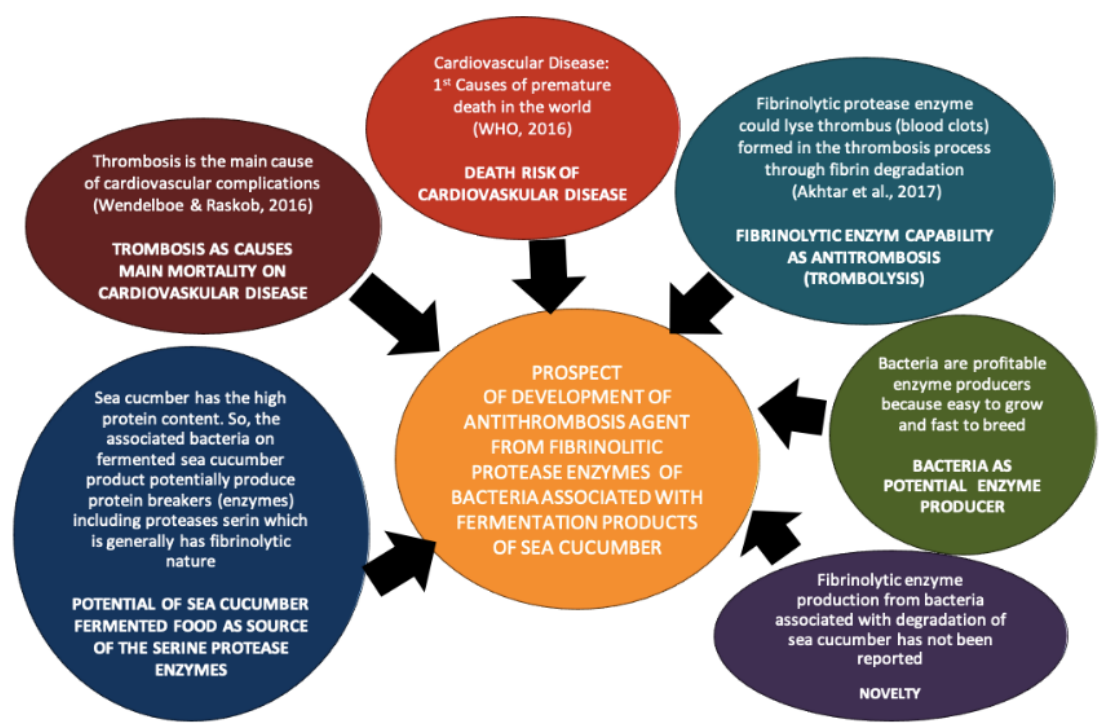

Fig. 1. Prospects for the production of antithrombotic agents in the form of protease enzymes from the results of proteolytic bacterial secretion in the fermented sea cucumber. 


\section{Conclusion}

Based on results of this review, majority of proteolytic bacteria isolated from fermented food belong to Bacillus group. Most bacteria producing fibrinolytic proteases applied in CVD treatment are also from Bacillus group. Studies about fibrinolytic protease enzymes of bacteria from sea cucumber fermentation products offers novelty and discovery of new proteolytic enzymes potential to be used in CVD treatment.

Authors deeply thank to Ministry of Research and Technology/National Agency for Research and Innovation (Kemenristek BRIN) or Indonesian Ministry or funding this work through Master Thesis Grant 2020.

\section{References}

1. L. Stephani, R.R. Tjandrawinata, D.N. Afifah, Y. Lim, W.T. Ismaya, M.T. Suhartono, Hayati J. Biosci., 24, 3, 124-130 (2017).

2. D.N. Afifah, M. Sulchan, D. Syah, Prev. Nutr. Food Sci., 19, 3, 213 (2014).

3. K.A. Hicks, K.W. Mahaffey, R. Mehran, S.E. Nissen, S.D. Wiviott, B. Dunn, D.A. Morrow, J. Am. Coll. Cardiol., 71, 9, 1021-1034 (2018).

4. D.B.Q. Anh, , N.T.T. Mi, P. Van Hung, Arab. J Sci. Eng., 40, 1, 23-28 (2015).

5. P. Bhatnagar, K. Wickramasinghe, J. Williams, M. Rayner, N. Townsend, Heart, 101, 15, 1182-1189 (2015).

6. E. Kotb, Biotechnol. Prog., 31, 2, 316-324 (2015).

7. R. Susanti, F. Fibriana, Teknologi Enzim, Yogyakarta: Andi Offset (2017). [in Bahasa Indonesia].

8. S. Bordbar, F. Anwar, N. Saari, Marine drugs, 10, 1761-1805 (2011).

9. Yao, Z., Kim, J.A., J.H. Kim, Food Sci Biotechnol., 27, 3, 765-772 (2018).

10. S.N. Ethica, R.R. Saptaningtyas, S.I. Muchlissin, A. Sabdono, Health and Technology,8, 4, 239-254 (2018).

11. K. Wright, C. McDaid, J. Med. Libr. Assoc.: JMLA, 99, 2, 164 (2011).

12. A. Liberati, D.G. Altman, J. Tetzlaff, C. Mulrow, P.C. Gøtzsche, J.P. Ioannidis, D. Moher, PLoS medicine, 6, 7, e1000100 (2009).

13. D.N.A. Huy, P.A. Hao, P.V. Hung, Int. Food Res. J., 23, 1 (2016).

14. B. Chen, J. Huo, Z. He, Q. He, Y. Hao, Z. Chen, Afr. J. Microbiol. Res., 7, 19, 2001-2009 (2013).

15. J. Yuan, J. Yang, Z. Zhuang, Y. Yang, L. Lin, S. Wang, BMC biotechnology, 12, 1, 36 (2012).

16. Y. Hu, D. Yu, Z. Wang, J. Hou, R. Tyagi, Y. Liang, Y. Hu, Sci. Rep., 9, 1, 9235 (2019).

17. F. Nailufar, R.R. Tjandrawinata, M.T. Suhartono, Adv. Pharmacol. Sci., 2016 (2016).
18. C.T. Chang, P.M. Wang, Y.F. Hung, Y.C. Chung, Food Chemistry, 133, 4, 1611-1617 (2012).

19. D. Choi, W.S. Cha, N. Park, H.W. Kim, J.H. Lee, J.S. Park, S.S. Park, Bioresour. Technol., 102, 3, 3279-3285 (2011).

20. Y. Devaraj, S.K. Rajender, P.M. Halami, Prep. Biochem. Biotech., 48, 2, 172-180 (2018).

21. X. Liu, N.K. Kopparapu, Y. Li, Y. Deng, X. Zheng, Int. J. Biol. Macromol., 94, 793-801 (2017).

22. D.W. Kim, J.H. Choi, S.E. Park, S. Kim, K. Sapkota, S.J. Kim, Int. J. Biol. Macromol., 72, 1159-1167 (2015).

23. X. Wei, M. Luo, L. Xu, Y. Zhang, X. Lin, P. Kong, H. Liu, J. Agric. Food Chem., 59, 8, 3957-3963 (2011).

24. S.J. Jeong, K. Heo, J.Y. Park, K.W. Lee, J.Y. Park, S.H. Joo, J.H. Kim, J. Microbiol. Biotechnol, 25, 1, 89-97 (2015).

25. P. Vijayaraghavan, P. Vincent, S. Gnana, BioMed research international, 2014 (2014).

26. X. Zhang, L.J. Yun, L.B. Peng, Y. Lu, K.P. Ma, F. Tang, J. Huazhong U. Sci.-Med. [Medical Sciences], 33, 1, 153-158 (2013).

27. K. Heo, K.M. Cho, C.K. Lee, G.M. Kim, J.H. Shin, J.S Kim, J.H. Kim, J. Microbiol. Biotechnol, 23, 7, 974-983 (2013).

28. H.D. Jo, H.A. Lee, S.J. Jeong, J.H. Kim, J. Microbiol. Biotechnol, 21, 11, 1166-1173 (2011).

29. A.A. Prihanto, M. Firdaus, J. Microbiol. Biotechnol. Food Sci., 2, 5, 2291 (2013).

30. H.H. Jeon, J.Y. Jung, B.H. Chun, M.D. Kim, S.Y. Baek, J.Y. Moon, C.O. Jeon, J. Microbiol. Biotechnol., 26, 666-674 (2016).

31. Z. Yao, X. Liu, J.M. Shim, K.W. Lee, H.J. Kim, J.H. Kim, J Microbiol. Biotechn., 27, 1, 9-18 (2017).

32. M.A. Almalki, D.S.D. Dhas, P. Vijayaraghavan, J. Sci. Res. 16, 2, 1-8 (2017).

33. D.A. Lestari, Isolasi Bakteri Penghasil Enzim Protease Pada Oncom Merah Pasca Fermentasi 72 Jam dan Identifikasi Molekuler Bakteri Berbasis Gen $16 S$ rRNA [Doctoral dissertation]. Universitas Muhammadiyah Semarang, Indonesia. (2018). [in Bahasa Indonesia].

34. W.O. Inayatul, S.I. Muchlissin, A. H. Mukaromah, S. Darmawati, S.N. Ethica, Isolasi dan Identifikasi Molekuler Bakteri Penghasil Enzim Protease Pseudomonas stutzeri ISTD4 dari Tempe Gembus Pasca Fermentasi 1 Hari. In Prosiding Seminar Nasional \& Internasional, 1, 1, (2018). [in Bahasa Indonesia] .

35. R. Safitri, S.I. Muchlissin, A. H. Mukaromah, S. Darmawati, S.N. Ethica. Isolasi Bakteri Penghasil Enzim Protease Bacillus thuringiensis IRODI Pada Oncom Merah Pasca Fermentasi 24 Jam. Seminar Nasional Edusainstek. (2019), pp. 62-69 [in Bahasa Indonesia]. 
36. A. Harun, S.I. Muchlissin, A. H. Mukaromah, S. Darmawati, S.N. Ethica. Isolasi Bakteri Penghasil Enzim Protease Staphylococcus hominis Pada Oncom Merah Pasca Fermentasi 120 Jam. In Prosiding Seminar Nasional \& Internasional, 1, 1, (2018). [in Bahasa Indonesia].

37. N.A. Japri, A.R. Sulistyaningtyas, S. Darmawati, S.N. Ethica, Isolasi dan Identifikasi Molekuler Bakteri Proteolitik Staphylococcus cohnii Strain IRLV5 pada Rusip Udang Putih (Litopeaneus Vannamei) Pasca Fermentasi 120 Jam Berdasarkan Analisis Gen 16s rRNA. In Prosiding Seminar Nasional Mahasiswa Unimus (Vol. 2), (2019). [in Bahasa Indonesia].

38. M. Fazri, A.I. Kartika, S. Darmawati, S.N. Ethica, Isolasi dan Identifikasi Molekuler Bakteri Staphylococcus epidermis pada Rusip Udang Windu (Penaeus monodon) Pasca Fermentasi 24 Jam Berdasarkan Sekuen Gen 16S rRNA. In Prosiding Seminar Nasional Mahasiswa Unimus (Vol. 2), (2019). [in Bahasa Indonesia]. 